\title{
EFEKTIVITAS PASTA GIGI HERBAL DAN NON HERBAL DALAM MENURUNKAN INDEKS PLAK PADA SISWA SMP MIFTAHUL ULUM SURABAYA TAHUN 2020
}

\author{
Ninggar Octaviani Rismanda Susanto ${ }^{1}$, Silvia Prasetyowati ${ }^{2}$, Agus Marjianto ${ }^{3}$ \\ ${ }^{1,2,3}$ Politeknik Kesehatan Kemenkes Surabaya Jurusan Keperawatan Gigi \\ E-mail : ninggar301098@gmail.com
}

Kata kunci:

Pasta Gigi

Herbal,

Pasta Gigi Non

Herbal,

Indeks plak

\section{ABSTRAK \\ EFEKTIVITAS PASTA GIGI HERBAL DAN NON HERBAL DALAM MENURUNKAN INDEKS PLAK PADA SISWA SMP MIFTAHUL ULUM SURABAYA TAHUN 2020}

Masalah dalam penelitian ini tingginya plak indeks siswa SMP Miftahul Ulum Surabaya Tahun 2020. Tujuan : Penelitian ini bertujuan untuk mengetahui efektivitas pasta gigi herbal dan non herbal dalam menurunkan indeks plak pada siswa SMP Miftahul Ulum Surabaya. Metode : Jenis penelitian yang digunakan adalah penelitian quasi eksperimen dengan rancangan pretest dan posttest desain. Subjek penelitian terdiri dari 80 siswa, metode pengumpulan data dengan cara observasi. teknik analisa data yang digunakan uji $\mathrm{T}$ tidak berpasangan (independent sample $T$ test). Hasil : pada penelitian ini diperoleh nilai Sig.(2-tailed) sebesar 0,017 dengan nilai rata-rata penurunan plak indeks sesudah pasta gigi herbal Mean \pm Std. Deviation $(1,7 \pm 0,54)$ dan pasta gigi non herbal Mean \pm Std. Deviation $(1,8 \pm 0,60)$ keduannya dapat menurunkan plak indeks. Ada perbedaan efektifitas menyikat gigi menggunakan pasta gigi herbal dan non herbal dalam menurunkan plak indeks, bahwa menyikat gigi menggunakan pasta gigi herbal lebih efektif dibandingkan menyikat gigi menggunakan pasta gigi non herbal.

Key word:

Herbal Toothpaste,

Non Herbal

Toothpaste,

Plaque Index
ABSTRACT

EFFECTIVENESS OF HERBAL AND NON HERBAL DENTAL PASTA IN REDUCING PLAQ INDEX IN MIFTAHUL ULUM SURABAYA JUNIOR HIGH SCHOOL IN 2020

The problem in this study is the high plaque index of Surabaya Miftahul Ulum Middle School students in 2019. Purpose: This study aims to determine the effectiveness of herbal and non herbal toothpaste in reducing the plaque index on Miftahul Ulum Middle School Surabaya students. Method: This type of research is a quasi-experimental study with a pretest and posttest design. The research subjects consisted of 80 students, the method of data collection by observation. the data analysis technique used is the independent sample T-test. Results: In this study, the Sig value (2-tailed) was 0.017 with an average value of index plaque reduction after herbal toothpaste Mean \pm Std. Deviation $(1.7 \pm$ $0.54)$ and non-herbal toothpaste Mean \pm Std. Deviation (1.8 \pm 0.60$)$ both can reduce the index plaque. There is a difference in the effectiveness of brushing teeth using herbal and non herbal toothpaste in reducing index plaque, that brushing teeth using 
herbal toothpaste is more effective than brushing teeth using non herbal toothpaste.

\section{PENDAHULUAN}

Plak gigi merupakan deposit lunak yang melekat erat pada permukaan gigi, terdiri atas mikroorganisme yang berkembang biak dalam suatu matrik interseluler jika seseorang melalaikan kebersihan gigi dan mulutnya. Berbeda halnya dengan lapisan terdahulu, plak gigi tidak dapat dibersihkan hanya dengan cara kumur ataupun semprotan air dan hanya dapat dibersihkan secara sempurna dengan cara mekanis. Plak biasanya mulai terbentuk pada sepertiga permukaan gingival dan pada permukaan gigi yang cacat dan kasar (Listrianah, 2017).

Plak memegang peranan penting dalam etiologi karies dan penyakit periodontal. Pencegahan karies dan penyakit periodontal dapat dilakukan dengan mencegah pembentukan plak dan pembersihan plak secara teratur. Usaha pengontrolan plak harus diarahkan pada dua tujuan yaitu membatasi jumlah Streptococcus mutans untuk pencegahan karies serta memelihara kesehatan gingiva dengan eliminasi plak pada area subgingiva secara mekanis maupun kimiawi (Susi dkk, 2015).

Pengontrolan plak secara mekanis dapat dilakukan dengan penyikatan gigi secara teratur. Pasta gigi merupakan bahan pembantu sikat gigi dalam menghambat pertumbuhan plak secara kimiawi. Penggunaan pasta gigi sebagai bahan abrasif berfungsi untuk membersihkan dan menghaluskan permukaan gigi (Susi dkk, 2015).

Persentase penduduk yang mempunyai masalah kesehatan gigi dan mulut di Indonesia menurut Riskesdas 2018 cukup tinggi yaitu sebesar 57,6\% dan yang mendapat pelayanan dari tenaga medis gigi sebesar 10,2\%. Adapun proporsi perilaku menyikat gigi dengan baik dan benar sebesar 2,8\%. Hal ini mengindikasikan masih rendahnya tingkat kesadaran masyarakat terhadap kesehatan giginya (Kemenkes RI, 2018).

Upaya penurunan angka indeks plak dapat dilakukan dengan cara menyikat gigi dengan cara yang tepat, banyak faktor yang mempengaruhi keberhasilan menyikat gigi misalnya : pengetahuan seseorang, sikat gigi dan pasta gigi yang digunakan, tekanan, dan jumlah plak dalam rongga mulut. Pasta gigi yang digunakan pada saat menyikat gigi berfungsi untuk menghilangkan debris, mengurangi pembentukan plak, memperkuat gigi terhadap karies, membersihkan dan memoles permukaan gigi, menghilangkan atau mengurangi bau mulut, memberikan rasa segar pada mulut serta memelihara kesehatan gusi (Rahmah dkk, 2014).

Penelitian yang menguji efektivitas pasta gigi herbal dengan komposisi utama siwak dengan berbagai bahan tambahan lain seperti Calcium carbonate sebagai bahan abrasive yang dapat membersihkan permukaan gigi tanpa merusak enamel, Water sebagai bahan pelarut, sorbitol sebagai bahan pelembab Sodium Lauryl Sulfate sebagai bahan deterjen, yang dapat melonggarkan ikatan debris dengan gigi dan akan membantu gerakan pembersihan sikat gigi (Rahmah, 2014).

\section{METODE}

Jenis penelitian yang digunakan adalah penelitian quasi eksperimen dengan rancangan pretest posttest with control group dengan pendekatan komparatif. yaitu data yang menyangkut variabel bebas atau resiko (Pasta Gigi Herbal dan non Herbal) dan variabel terikat atau akibat (Indeks Plak Gigi). Metode pengumpulan data pada penelitian ini menggunakan metode pemeriksaan dan observasi. Populasi penelitian ini adalah siswa siswi SMP Miftahul Ulum Surabaya dengan jumlah responden sebanyak 100 orang. Kemudian pengambilan sampel menggunakan metode simple random sampling dengan 
cara pengambilan sampel yaitu proporsional dan jumlah sampel yang didapat sebanyak 80 responden. Pemeriksaan dilakukan pada mahkota gigi bagian fasial atau lingual dengan membagi tiap permukaan mahkota gigi menjadi lima subdivisi yaitu: $D$, distal; $G$, sepertiga tengah gingival; $\mathrm{M}$, mesial; $\mathrm{C}$, sepertiga tengah; I/O, sepertiga tengah insisal atau oklusal. Kemudian setelah memeriksa rongga mulut responden, peneliti melakukan observasi pada responden yang telah diperiksa. Uji analisis pada penelitian ini menggunakan uji T tidak berpasangan (independent sample T test).

\section{HASIL DAN PEMBAHASAN}

Data penelitian diperoleh dari hasil perhitungan plak indeks menggunakan teknik PHP (Personal Hygiene Performance Index) yang dilaksanakan pada tanggal 12 oktober 2019 15 februari 2020 di SMP Miftahul Ulum Surabaya. Dari 80 responden yang sudah memenuhi kriteria sebagai sampel penelitian dibagi menjadi 2 kelompok perlakuan, yaitu 40 siswa di kelompok 1 setelah gosok gigi menggunakan pasta gigi herbal dan 40 siswa di kelompok 2 setelah gosok gigi menggunakan pasta gigi non herbal. Setelah didapat sampel yang diinginkan, barulah dilakukan penelitian dengan melakukan pemeriksaan perhitungan plak indeks sebelum dan sesudah menggosok gigi menggunakan pasta gigi herbal dan non herbal. Dari proses pemeriksaan plak tersebut, didapatkan hasil perhitungan perbedaan plak indeks sebelum dan sesudah menggosok gigi herbal dan non herbal.

\section{Tabel 1 : Hasil Analisis Data Nilai Plak Indeks Sebelum Dan Sesudah Menggunakan Pasta Gigi Herbal (Penurunan Nilai Plak Indeks Sebelum Dan Sesudah Menggunakan Pasta Gigi Herbal)}

$\mathbf{N}=40$ siswa

\begin{tabular}{cccccc}
\hline Variabel & \multicolumn{2}{c}{ Sebelum } & \multicolumn{2}{c}{ Sesudah } & $\begin{array}{c}\text { Rata-rata } \\
\text { selisih } \\
\text { penurunan } \\
\text { plak }\end{array}$ \\
\cline { 2 - 5 } & Rata-rata & Kategori & Rata-rata & Kategori & indeks \\
\hline $\begin{array}{c}\text { Pasta } \\
\text { gigi } \\
\text { herbal }\end{array}$ & $\mathbf{2 , 9}$ & Sedang & $\mathbf{1 , 7}$ & Baik & 1,2 \\
\hline
\end{tabular}

Berdasarkan tabel 5.1 diketahui bahwa nilai rata-rata plak indeks sebelum $(2,9)$ dan sesudah diberikan perlakuan $(1,7)$ dengan rata-rata selisih penurunan sebesar $(1,2)$. 
Tabel 2 : Hasil Analisis Data Nilai Plak Indeks Sebelum Dan Sesudah Menggunakan Pasta Gigi Non Herbal (Penurunan Nilai Plak Indeks Sebelum Dan Sesudah Menggunakan Pasta Gigi Non Herbal)

$\mathbf{N}=40$ siswa

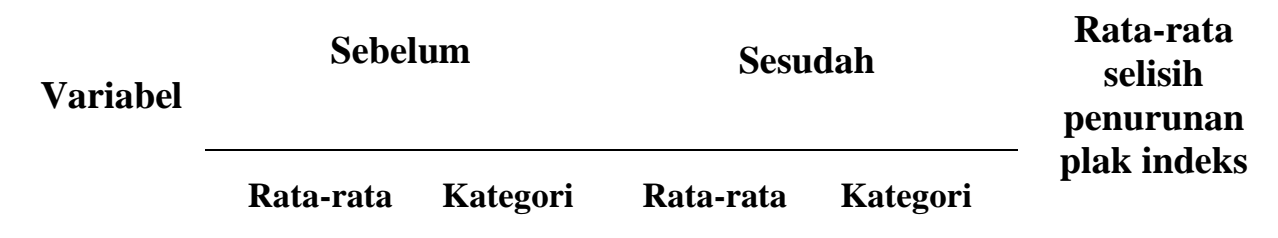

\begin{tabular}{cccccc}
\hline $\begin{array}{c}\text { Pasta } \\
\text { gigi } \\
\text { non } \\
\text { herbal }\end{array}$ & $\mathbf{2 , 9 2}$ & Sedang & $\mathbf{1 , 8}$ & Sedang & 1,12 \\
\hline
\end{tabular}

Berdasarkan tabel 5.2 diketahui bahwa nilai rata-rata plak indeks sebelum $(2,92)$ dan sesudah diberi perlakuan $(1,8)$ dengan rata-rata selisih penurunan sebesar $(1,12)$.

Tabel 3 : Uji Normalitas Nilai Plak Indeks Sebelum Dan Sesudah Menggunakan Pasta Gigi Herbal dan Non Herbal

$\mathbf{N}=40$ siswa

\begin{tabular}{lccccc}
\hline \multirow{2}{*}{ Variabel } & \multicolumn{5}{c}{ Uji Normalitas kolmogorov smirnov } \\
\cline { 2 - 6 } & $\boldsymbol{N}$ & Min & Max & Mean \pm Std.Deviation & Sig. \\
\hline $\begin{array}{l}\text { Plak indeks } \\
\text { sebelum } \\
\text { herbal }\end{array}$ & 40 & 1,2 & 4,5 & $2,9 \pm 0,90$ & 0,103 \\
\hline $\begin{array}{l}\text { Plak indeks } \\
\text { sesudah herbal }\end{array}$ & 40 & 1,0 & 3,0 & $1,7 \pm 0,61$ & 0,058 \\
\hline
\end{tabular}

Berdasarkan tabel 5.3 hasil uji normalitas didapatkan nilai signifikasi penurunan nilai plak indeks sebelum dan sesudah menggosok gigi dengan pasta herbal 0,103 dan 0,058 dapat disimpulkan kedua data hasil penelitian berdistribusi normal karena apabila nilai signifikasi (Sig.) $>0,05$ maka data penelitian berdistribusi normal. 
Tabel 4 : Uji Normalitas Nilai Plak Indeks Sebelum Dan Sesudah Menggosok gigi Menggunakan Pasta Gigi Non Herbal

$\mathbf{N}=40$ siswa

\begin{tabular}{lccccc}
\hline \multirow{2}{*}{ Variabel } & \multicolumn{5}{c}{ Uji Normalitas kolmogorov smirnov } \\
\cline { 2 - 6 } & $\boldsymbol{N}$ & Min & Max & Mean \pm Std.Deviation & Sig. \\
\hline $\begin{array}{l}\text { Plak indeks } \\
\text { sebelum } \\
\text { non herbal }\end{array}$ & 40 & 1,2 & 4,5 & $2,92 \pm 0,85$ & 0,103 \\
\hline $\begin{array}{l}\text { Plak indeks } \\
\text { sesudah non } \\
\text { herbal }\end{array}$ & 40 & 1,0 & 3,0 & $1,8 \pm 0,60$ & 0,182 \\
\hline
\end{tabular}

Berdasarkan tabel 5.4 hasil uji normalitas didapatkan nilai signifikasi penurunan nilai plak indeks sebelum dan sesudah menggosok gigi dengan pasta non herbal 0,103 dan 0,182 dapat disimpulkan kedua data hasil penelitian berdistribusi normal karena apabila nilai signifikasi (Sig.) > 0,05 maka data penelitian berdistribusi normal.

Tabel 5 : Uji Independent Simple T-Test Perbedaan Efektifitas Pasta Gigi Herbal Dan Non Herbal Dalam Menurunkan Angka Plak Indeks

$\mathbf{N}=40$ siswa

\begin{tabular}{lccccc}
\hline \multirow{2}{*}{ Variabel } & $\boldsymbol{N}$ & Min & Max & $\begin{array}{c}\text { Mean } \pm \\
\text { Std.Deviation }\end{array}$ & Sig.(2-tailed) \\
\cline { 2 - 5 } & 40 & 1,2 & 4,5 & $1,7 \pm 0,54$ & 0,017 \\
\hline $\begin{array}{l}\text { Plak } \\
\text { indeks } \\
\text { sesudah } \\
\text { herbal }\end{array}$ & 4,5 independent simple t-test & \\
\hline $\begin{array}{l}\text { Plak indeks } \\
\text { sesudah non } \\
\text { herbal }\end{array}$ & 40 & 1,0 & 3,0 & $1,8 \pm 0,60$ & 0,017 \\
\hline
\end{tabular}

Berdasarkan tabel 5.5 hasil uji $\mathrm{T}$ tidak berpasangan (independent sampel $T$ test) didapatkan nilai Sig. (2-tailed) sebesar 0,017 yang berarti nilai $p$ (signifikasi) lebih kecil dari nilai tingkat signifikan $\alpha(0,05)$, apabila nilai Sig. (2-tailed) sebesar 0,017 < 0,05 (nilai tingkat signifikan $\alpha$ ), maka dapat disimpulkan $\mathrm{H} 0$ ditolak dan $\mathrm{H}_{1}$ diterima yang berarti bahwa ada perbedaan yang signifikan. Terlihat dari besarnya rata-rata penurunan nilai plak indeks sebelum dan sesudah menggunakan pasta gigi herbal dan non herbal, dapat di simpulkan bahwa penggunaan pasta gigi dalam penelitian ini lebih efektif menggunakan pasta gigi herbal di bandingkan pasta gigi non herbal, karena mempunyai rata-rata penurunan nilai plak indeks yang lebih besar.

Salah satu faktor terpenting yang kemungkinan dapat mempengaruhi indeks plak adalah tindakan kebersihan mulut. Ada beberapa cara tindakan kebersihan gigi dan mulut, yaitu membersihkan plak dengan cara mekanis dan kimiawi. Dengan cara mekanis yaitu dengan bantuan benang gigi dan juga dengan menyikat gigi. Sedangkan dengan cara kimiawi yaitu dengan pasta gigi dan juga obat kumur. Bahan pasta gigi juga berpengaruh yaitu yang memiliki sifat terapeutik yang salah satu bahannya ditambahkan dalam pasta 
gigi yang berasal dari tubuhan (herbal) yang diharapkan dapat menghambat akumulasi plak.

\section{Efektivitas Sebelum dan Sesudah Menyikat gigi menggunakan pasta gigi herbal terhadap penurunan plak indeks}

Berdasarkan hasil penelitian di dapatkan nilai rata-rata plak indeks sebelum dan sesudah menyikat gigi menggunakan pasta gigi herbal mengalami penurunan yang signifikan. Hasil perhitungan plak indeks setelah diberikan perlakuan menyikat gigi menggunakan pasta gigi herbal didapat hasil penurunan yang signifikan yaitu nilai rata-rata plak indeks siswa dari kategori sedang menjadi baik hal ini juga disebabkan partisipasi aktif dari para siswa serta teknik menyikat gigi yang baik dan benar sesuai instruksi dari peneliti.

Hal ini sejalan dengan penelitian yang dilakukan Oroh, dkk (2015) yang menyatakan bahwa hasil penilaian indeks plak gigi selain dipengaruhi oleh tindakan penyikatan gigi, juga dipengaruhi oleh kelebihan daya antibakteri dalam siwak serta kandungan minyak atsiri pada daun sirih dalam pasta gigi herbal. Daya antibakteri minyak atsiri disebabkan oleh adanya senyawa fenol dan turunannya yang dapat mendenaturasi protein sel bakteri. Siwak dapat menghambat pertumbuhan dan perkembangan bakteri rongga mulut terutama spesies Streptococcus. Tannin (asam tanan) yang terkandung didalam siwak dapat mengurangi perlekatan bakteri pada permukaan gigi.

Sejalan dengan penelitian yang dilakukan Oroh, dkk (2015) tersebut juga didapatkan penelitian dengan hasil bertentangan yang dilakukan oleh Dewantara dkk (2015) yang menyatakan bahwa semua bahan aktif baik herbal maupun non herbal yang terdapat dalam pasta gigi secara klinis menunjukan efek yang sama dalam menurunkan indeks plak rongga mulut. Penyikatan gigi dengan menggunakan pasta gigi non herbal dapat menurunkan indeks plak secara bermakna. Hal tersebut disebabkan terdapat bahan abrasif yang dapat membersihkan dan memoles permukaan gigi tanpa merusak email.

Kandungan herbal pada pasta gigi diharapkan dapat membersihkan debris atau deposit plak pada permukaan gigi dan gusi sehingga dapat mencegah penyakit gigi dan mulut lebih lanjut. Hal tersebut berkaitan dengan kemampuan beberapa jenis herbal yang mampu menghambat pertumbuhan mikroba. Selain itu, karena herbal berasal dari tumbuhtumbuhan, maka bahan tersebut aman dan alami (Listrianah, 2017)

\section{Efektivitas Sebelum dan Sesudah Menyikat gigi menggunakan pasta gigi non herbal terhadap penurunan plak indeks}

Berdasarkan hasil penelitian di dapatkan nilai rata-rata plak indeks sebelum dan sesudah menyikat gigi menggunakan pasta gigi non herbal mengalami penurunan yang kurang signifikan. Hasil perhitungan plak indeks setelah diberikan perlakuan menyikat gigi menggunakan pasta gigi non herbal didapat hasil penurunan yang kurang signifikan yaitu nilai rata-rata plak indeks siswa dari kategori sedang menjadi tetap sedang, hal ini dapat di sebabkan beberapa faktor yang mungkin terjadi yaitu tidak adanya kandungan bahan aktif antibakteri pada pasta gigi non herbal.

Kandungan lain pada pasta gigi non-herbal yaitu adanya bahan yang bersifat abrasif. Bahan abrasif mampu membantu meningkatkan daya eliminasi terhadap plak sehingga plak yang menempel pada permukaan gigi dapat tereleminasi. Sehingga dapat dibuktikan bahwa menyikat gigi menggunakan pasta gigi non herbal mampu menurunkan nila ratarata plak indeks siswa meskipun hasil yang di dapatkan kurang signifikan dibandingkan dengan menyikat gigi menggunakan pasta gigi herbal (Puspitasari, dkk, 2018) 


\section{Perbedaan Efektivitas Menyikat gigi menggunakan pasta gigi herbal dengan pasta gigi non herbal terhadap penurunan plak indeks}

Didapatkan hasil bahwa terdapat perbedaan efektifitas plak indeks antara menyikat gigi menggunakan pasta gigi herbal dan pasta gigi non herbal terhadap plak indeks. Hal tersebut dapat dilihat dimana penurunan nilai rata-rata plak indeks sesudah menyikat gigi menggunakan pasta gigi herbal lebih tinggi dibandingkan dengan penurunan rata-rata plak indeks sesudah menyikat gigi menggunakan pasta gigi non herbal.

Faktor lain yang mempengaruhi adalah pengendalian plak secara mekanis dan kimiawi. Salah satu indikator dari kebersihan gigi dan mulut adalah tingkat kebersihan dari rongga mulut. Pemeliharaan kebersihan gigi dan mulut secara teratur dapat dimulai dengan melakukan kontrol plak baik secara mekanis yaitu

menyikat gigi dan kimiawi berupa penggunaan pasta gigi. Pasta gigi yang diujikan pada penelitian ini merupakan jenis pasta gigi berbahan herbal dan non herbal kimiawi yang masing-masing pasta mengandung bahan aktif antibakteri untuk dapat menghambat pembentukan plak dan pencegahan gingivitis (Gina, dkk, 2018).

Perubahan hasil penelitian indeks plak gigi juga disebabkan karena dalam kedua pasta gigi tersebut terdapat bahan abrasif yang mampu meningkatkan daya abrasif sikat gigi sehingga lebih memudahkan pembersihan dan pemolesan gigi tanpa merusak email. Pasta gigi juga mengandung bahan pembersih yang berfungsi menurunkan tegangan permukaan dan melonggarkan ikatan debris dengan gigi yang akan membantu gerakkan pembersihan sikat gigi. Tekanan bulu sikat yang dihasilkan lewat tindakan menyikat menyebabkan sisa makanan dan plak pada permukaan gigi hilang atau berkurang (Puspitasari dkk, 2018).

\section{KESIMPULAN}

Berdasarkan hasil penelitian tentang efektivitas pasta gigi herbal dan non herbal dalam menurunkan indeks plak pada siswa SMP MIFTAHUL ULUM SURABAYA Tahun 2020

1. Rata-rata plak indeks siswa kelas 7,8, dan 9 SMP Miftahul Ulum Surabaya sebelum di berikan perlakuan menggosok gigi dengan pasta herbal termasuk dalam kategori sedang, sedangkan sesudah di berikan perlakuan menggosok gigi dengan pasta herbal termasuk dalam kategori baik.

2. Rata-rata debris indeks plak indeks siswa kelas 7,8, dan 9 SMP Miftahul Ulum Surabaya sebelum di berikan perlakuan menggosok gigi dengan pasta non herbal termasuk dalam kategori sedang, sedangkan sesudah di berikan perlakuan menggosok gigi dengan pasta non herbal termasuk dalam kategori sedang.

3. Terdapat perbedaan efektifitas pasta gigi herbal dan pasta gigi non herbal terhadap penurunan plak indeks pada siswa kelas 7,8, dan 9 SMP Miftahul Ulum Surabaya Tahun 2020.

\section{DAFTAR PUSTAKA}

Dewantara, D., Putra, A., Astuti, P., \& Rochim, A. 2015. Uji Klinis Penggunaan Pasta Gigi Herbal Terhadap Penurunan Indeks Plak Rongga Mulut. E-Jurnal Pustaka Kesehatan, Vol. 3, Hal. 224-229.

Gina, D. N., \& Ramayanti, I. (2018). Perbandingan Efektivitas Berbagai Jenis Pasta Gigi Bahan Herbal dan Pasta Gigi Bahan Non Herbal Terhadap Pembentukan Plak.

Kementrian Kesehatan Republik Indonesia. (2018). Laporan Nasional Riset Kesehatan Dasar 2018. Hal. 197,221. 
Listrianah. (2017). Hubungan Menyikat Gigi dengan Pasta Gigi yang Mengandung Herbal terhadap Penurunan Skor Debris pada Pasien Klinik Gigi An-Nisa Palembang. Jurusan Keperawatan Gigi Poltekkes Kemenkes Palembang, Vol. 12, Hal. 83-94.

Oroh, E. S., Posangi, J., \& Wowor, V. N. S. (2015). Perbandingan Efektivitas Pasta Gigi Herbal Dengan Pasta Gigi Non Herbal Terhadap Penurunan Indeks Plak Gigi. E-GIGI, Vol. 3, Hal. 573-578.

Puspitasari, A., Balbeid, M., Abdurrahman., A. (2018). Perbedaan Pasta Gigi Herbal dan Non Herbal Terhadap Penurunan Plak Indeks Score pada Anak.

Rahmah, R. Y., Rachmadi, P., \& Widodo. 2014. Perbandingan Efektivitas Pasta Gigi Herbal Dengan Pasta Gigi Non Herbal Terhadap Penurunan Indeks Plak Gigi. E-GIGI, Vol. 2, Hal. 120-124.

Susi, S., Bachtiar, H., \& Sali, N. 2015. Perbedaan Daya Hambat Pasta Gigi Berbahan Herbal Terhadap Pertumbuhan Streptococcus Mutans. Majalah Kedokteran Andalas, Vol. 38, Hal. 116-123. 